\title{
The impact of Covid-19 pandemic over the dental patients
}

\author{
O impacto da pandemia de Covid-19 sobre os pacientes odontológicos \\ El impacto de la pandemia de Covid-19 en los pacientes dentales
}

\author{
Received: 08/17/2021 | Reviewed: 08/22/2021 | Accept: 08/28/2021 | Published: 08/30/2021 \\ Lara Steffany de Carvalho \\ ORCID: https://orcid.org/0000-0002-3166-8180 \\ Instituto Nacional de Ensino Superior e Pós-Graduação Padre Gervásio, Brazil \\ E-mail: larasteffany2011@gmail.com \\ Caroline Trefiglio Rocha \\ ORCID: https://orcid.org/0000-0002-3824-1841 \\ Universidade Estadual Paulista, Brazil \\ E-mail: caroline.trefiglio@unesp.br \\ Rafael de Aguiar Vilela Júnior \\ ORCID: https://orcid.org/0000-0001-6312-6637 \\ Instituto Nacional de Ensino Superior e Pós-Graduação Padre Gervásio, Brazil \\ E-mail: rafaelvilelajr@yahoo.com.br \\ Ivan Balducci \\ ORCID: https://orcid.org/0000-0003-2569-083X \\ Universidade Estadual Paulista, Brazil \\ E-mail: ivan.balducci@unesp.br \\ Amjad Abu Hasna \\ ORCID: https://orcid.org/0000-0002-1112-985X \\ Instituto Nacional de Ensino Superior e Pós-Graduação Padre Gervásio, Brazil \\ Universidade Estadual Paulista, Brazil \\ E-mail: d.d.s.amjad@gmail.com
}

\begin{abstract}
Objective: Covid-19 is a highly infectious disease; it is transmitted by patients' secretions and respiratory droplets SARS-CoV-2 was detected in patients saliva making dental care professionals more susceptible for contamination and the patient less safe while seeking the dental treatment. Methodology: This quantitative study was elaborated through a questionnaire for patients who frequently seek dental care in private and publica dental care units. A total of 205 over-18 patients were included, those who left one or more questions without answer were excluded. Participants were able to refuse to answer any question or to participate in the questionnaire at all. The questionnaire was composed of five questions. Participants were divided into two groups: Group 1: private dental offices patients $(n=98)$; Group 2: public dental clinic patients $(\mathrm{n}=107)$. Results: there was a significant difference between groups 1 and 2 , in which $50 \%$ of group 1 feel safe while seeking dental care during the Covid-19 pandemic in comparison with $72.89 \%$ of group 2. There was no significant difference between groups 1 and 2, in which 93.87 and $94.39 \%$ of groups 1 and 2 respectively feel safe with the professionals' PPE and consider it sufficient. About $59.81 \%$ of the participants of group 2 do not feel insecure with the cross contamination caused by SARS-CoV-2 in collective health care units. Finally, there was a significant difference between groups 1 and 2, in which $74.48 \%$ of group 1 prefer to be attended by vaccinated professionals, instead of only $56.07 \%$ of group 2 . Conclusion: it was concluded that not all dental patients feel safe while seeking dental treatment during the Covid-19 pandemic, however, they consider the professional PPE sufficient. Patients feel safe to be attended by vaccinated professionals.
\end{abstract}

Keywords: SARS-CoV-2; Covid-19; Dentist; Dental patient; Vaccine.

\section{Resumo}

Objetivo: Covid-19 é uma doença altamente infecciosa; é transmitido pelas secreções e gotículas respiratórias dos pacientes. O SARS-CoV-2 foi detectado na saliva dos pacientes, tornando os profissionais de atendimento odontológico mais suscetíveis à contaminação e o paciente menos seguro ao procurar o tratamento odontológico. Metodologia: Estudo quantitativo foi elaborado por meio de questionário para pacientes que buscam com frequência atendimento odontológico em unidades odontológicas privadas e públicas. Foram incluídos 205 pacientes maiores de 18 anos, excluídos aqueles que deixaram uma ou mais perguntas sem resposta. Os participantes puderam se recusar a responder a qualquer pergunta ou a participar do questionário. O questionário foi composto por cinco questões. Os participantes foram divididos em dois grupos: Grupo 1: pacientes de consultórios odontológicos privados $(\mathrm{n}=98)$; Grupo 2: pacientes de clínica odontológica pública $(\mathrm{n}=107)$. Resultados: houve diferença significativa entre os grupos 1 e 2, em que 50\% do grupo 1 se sentem seguros ao buscar atendimento odontológico durante a pandemia de Covid-19 em comparação com 72,89\% do grupo 2. Não houve diferença significativa entre os grupos 1 e 2, no qual 
93,87 e 94,39\% dos grupos 1 e 2, respectivamente, sentem-se seguros com os EPIs dos profissionais e os consideram suficientes. Cerca de 59,81\% dos participantes do grupo 2 não se sentem inseguros com a contaminação cruzada causada pelo SARS-CoV-2 nas unidades coletivas de saúde. Por fim, houve diferença significativa entre os grupos 1 e 2 , em que $74,48 \%$ do grupo 1 preferem ser atendidos por profissionais vacinados, ao invés de apenas $56,07 \%$ do grupo 2. Conclusão: concluiu-se que nem todos os pacientes odontológicos se sentem seguros enquanto buscando tratamento odontológico durante a pandemia de Covid-19, entretanto, consideram o EPI do profissional suficiente. Os pacientes se sentem seguros ao serem atendidos por profissionais vacinados.

Palavras-chave: SARS-CoV-2; Covid19; Dentista; Paciente odontológico; Vacina.

\section{Resumen}

Propósito: Covid-19 es una enfermedad altamente infecciosa; se transmite por las secreciones respiratorias y las gotitas de los pacientes. El SARS-CoV-2 se detectó en la saliva de los pacientes, lo que hace que los profesionales de la atención dental sean más susceptibles a la contaminación y que el paciente esté menos seguro cuando busca tratamiento dental. Metodología: El estudio cuantitativo se desarrolló a través de un cuestionario para pacientes que frecuentemente buscan atención odontológica en unidades odontológicas privadas y públicas. Se incluyeron un total de 205 pacientes mayores de 18 años, excluidos los que dejaron una o más preguntas sin responder. Los participantes pueden negarse a responder a cualquier pregunta oa participar en el cuestionario. El cuestionario constaba de cinco preguntas. Los participantes se dividieron en dos grupos: Grupo 1: pacientes de consultorios dentales privados ( $\mathrm{n}=$ 98); Grupo 2: pacientes de una clínica dental pública $(\mathrm{n}=107)$. Resultados: hubo una diferencia significativa entre los grupos 1 y 2, en los que el 50\% del grupo 1 se sintió seguro al buscar atención dental durante la pandemia Covid-19 en comparación con el 72,89\% del grupo 2. No hubo diferencia significativa entre los grupos 1 y 2, en el que el 93,87 y el 94,39\% de los grupos 1 y 2, respectivamente, se sienten seguros con los EPI de los profesionales y los consideran suficientes. Aproximadamente el 59,81\% de los participantes del grupo 2 no se sienten inseguros con la contaminación cruzada causada por el SARS-CoV-2 en las unidades de salud colectiva. Finalmente, hubo una diferencia significativa entre los grupos 1 y 2, en el que el 74,48\% del grupo 1 prefiere ser atendido por profesionales vacunados, en lugar de solo el 56,07\% del grupo 2. Conclusión: se concluyó que no todos los pacientes dentales se sienten seguros mientras buscando tratamiento dental durante la pandemia de Covid-19, sin embargo, consideran suficiente el EPP del profesional. Los pacientes se sienten seguros cuando son atendidos por profesionales vacunados.

Palabras clave: SARS-CoV-2; COVID-19; Dentista; Paciente dental; Vacuna.

\section{Introduction}

Severe acute respiratory syndrome coronavirus 2 "SARS-CoV-2" that causes coronavirus disease of 2019 "Covid19”, belongs to $\beta$ genus Coronavirus of the coronaviridae family (H. Y. Tian, 2020). Its genome characterization suggests similarity with the severe acute respiratory syndrome coronavirus "SARS-CoV" and Middle East respiratory syndrome coronavirus "MERS-CoV" (Zhou et al., 2020). It has a positive-sense, single-stranded RNA genome of 30 kb (Kim et al., 2020) which encodes three membrane proteins (Mandala et al., 2020) making its deactivation possible with sodium hypochlorite (Amjad Abu Hasna \& Bresciani, 2021). However, after entry and replication of the genome in host cells, SARSCoV-2 maintains a series of strategies to prevent the host's immune system from recognizing it, and adheres to receptors throughout the human body in order to replicate (Mohamadian et al., 2021).

The common symptoms of Covid-19 include: fever, cough, shortness of breath, fatigue, headache, loss of taste or smell, sore throat, congestion or runny nose, nausea or vomiting, and diarrhea, among others. However, many variants of SARS-CoV-2 was reported by the world health organization "WHO" (World Health Organization, 2021) using the pangolin “Phylogenetic Assignment of Named Global Outbreak" Lineages nomenclature tool (O'Toole et al., 2021) alerting the need for rapid containing of Covid-19 to prevent further mutations of SARS-CoV-2 (Callaway, 2021).

Covid-19 is a highly infectious disease, it is transmitted by patients' secretions and respiratory droplets (Nishwa, Riaz, Fatima, \& Wahid, 2020). SARS-CoV-2 was detected in patients saliva (To et al., 2020) making dental care professionals more susceptible for contamination (Jurema et al., 2020). The dental care was restricted to emergent and urgent cases upon the pandemic onset (Kılıçarslan, Şenel, \& Özcan, 2020) using strict protocols to avoid dentist-patient and patient-patient contaminations (Jurema et al., 2020). National and international health authorities reinforced the use of personal protective equipment "PPE" including N-95 masks and face shields beside the anteriorly used PPE (Jurema et al., 2020; Pan et al., 2020), 
in addition to vaccine to control the pandemic (X. Tian et al., 2020)

Because of SARS-CoV-2 high pathogenicity, lethality and spreading (Mohamadian et al., 2021), an effective vaccine would be crucial in controlling the pandemic, ending social distancing and resolving the socioeconomic implications caused by the spread of the virus around the world. The vaccine development encompasses a series of clinical and laboratory trials that take years to be finalized and scientifically proven (Lima, Almeida, \& Kfouri, 2021). In this race against time, vaccines against Covid-19 were produced in a record time, and four types of vaccines have been applied in Brazil to date.

The objective of this paper was to understand the impact of Covid-19 on dental care service through a questionnaire directed for dental patients. The null hypothesis is that the dental patients feel safe with the professionals' PPE.

\section{Methodology}

This quantitative study was elaborated through a questionnaire for patients who frequently seek dental care in Minas Gerais state, at private dental offices in the cities of Pouso Alegre and Itajubá, dental clinic of the National Institute of Higher Education and Post-graduation Priest Gervásio "INAPÓS", and at primary health unit "UBS" in the city of Cambuí.

This study was approved and authorized by the Ethics Committee of São Paulo State University, Institute of Science and Technology ICT-Unesp (protocol 4.909.386). All participants signed an informed consent form. Participants were able to refuse to answer any question or to participate in the questionnaire at all.

\section{Inclusion criteria}

- Over-18 patients.

- Patients who answered all the questions.

- Patients who accepted to sign the informed consent form and participate in the questionnaire voluntarily.

\section{Exclusion criteria}

- Under-18 patients.

- Patients who left one or more questions without answer.

- Patients who refused to sign the informed consent form and participate in the questionnaire voluntarily.

\section{Patients' questionnaire}

This study was performed in July 2021. The questionnaire was composed of five questions. A total of 205 participants were included in this study and divided into two groups:

- Group 1: private dental offices patients ( $\mathrm{n}=98)$;

- Group 2: dental clinic of INAPÓS and UBS patients ( $\mathrm{n}=107)$.

All participants of both groups received a standardized questionnaire focusing on their safety while seeking dental care during the Covid-19 pandemic, their acceptance of the professionals PPE and protocols, and their acceptance of the vaccine (Table 1). 
Table 1. The patient's questionnaire about their feelings and preference while seeking dental care during the Covid-19 pandemic

\begin{tabular}{|l|l|}
\hline \multicolumn{2}{|l|}{ Question 1: Have you been attended during the period of the Covid-19 pandemic? } \\
\hline YES \\
\hline Question 2: Do you feel safe while seeking dental care during the Covid-19 pandemic? \\
\hline YES \\
\hline Question 3: Do you feel safe with the professionals' PPE and consider it sufficient? \\
\hline YES & NO INDIFFERENT \\
\hline \begin{tabular}{l} 
Question 4: (For the INAPÓS and UBS patients only) Would you be insecure with the cross \\
\hline contamination caused by SARS-CoV-2 in collective health care units?
\end{tabular} \\
\hline YES \\
\hline Question 5: Do you prefer to be attended by a vaccinated professional? \\
\hline YES & NO \\
\hline
\end{tabular}

Source: Authors.

\section{Statistical analysis}

For data analysis, multprop macro was used as in previous studies (A. Abu Hasna, Ferrari, Bittencourt, Camargo, \& Carvalho, 2019; A A Hasna, Pinto, Minhoto, Carvalho, \& Ferrari, 2020) to perform multiple comparisons tests on proportion data using Tukey's honest significant difference test with a significance level $(\alpha \leq 0.05)$. Data analysis was performed by Minitab (Minitab® 17.1.0, by Microsoft, USA). This macro requires two input columns, where the first column contains the number of successes (or the right answers), and the second column contains only integer data. In questions 1, 2, 3 and 5, the answer YES was considered as success or right answers. It was not possible to analyze the data of question 4 as it was assigned for group 2 only.

\section{Results}

\section{Patients' questionnaire}

In question 1, all the participants of both groups confirmed that they have been attended during the period of the Covid-19 pandemic. In question 2, there was a significant difference between groups 1 and 2, in which 50\% of group 1 feel safe while seeking dental care during the Covid-19 pandemic in comparison with $72.89 \%$ of group 2 (Figure.1). 
Figure 1. The answers rate of question 2. Different letters indicate statistical difference between the groups. $(1=$ group $1 ; 2=$ group 2).

\section{Do you feel safe while seeking dental care during the Covid-19 pandemic?}

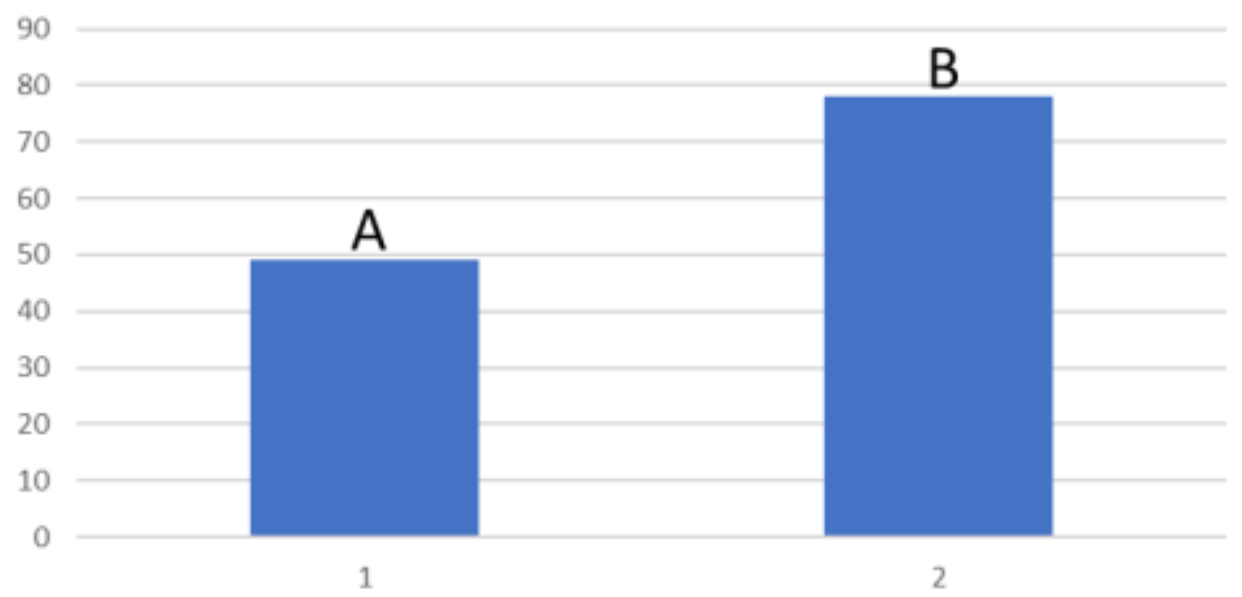

Source: Authors.

In question 3, there was no significant difference between groups 1 and 2, in which 93.87 and $94.39 \%$ of groups 1 and 2 respectively feel safe with the professionals' PPE and consider it sufficient (Figure.2). In question $4,59.81 \%$ of the participants of group 2 do not feel insecure with the cross contamination caused by SARS-CoV-2 in collective health care units.

Figure 2. The answers rate of question 3. Different letters indicate statistical difference between the groups. $(1=$ group $1 ; 2=$ group 2).

\section{Do you feel safe with the professionals' PPE and consider it sufficient?}

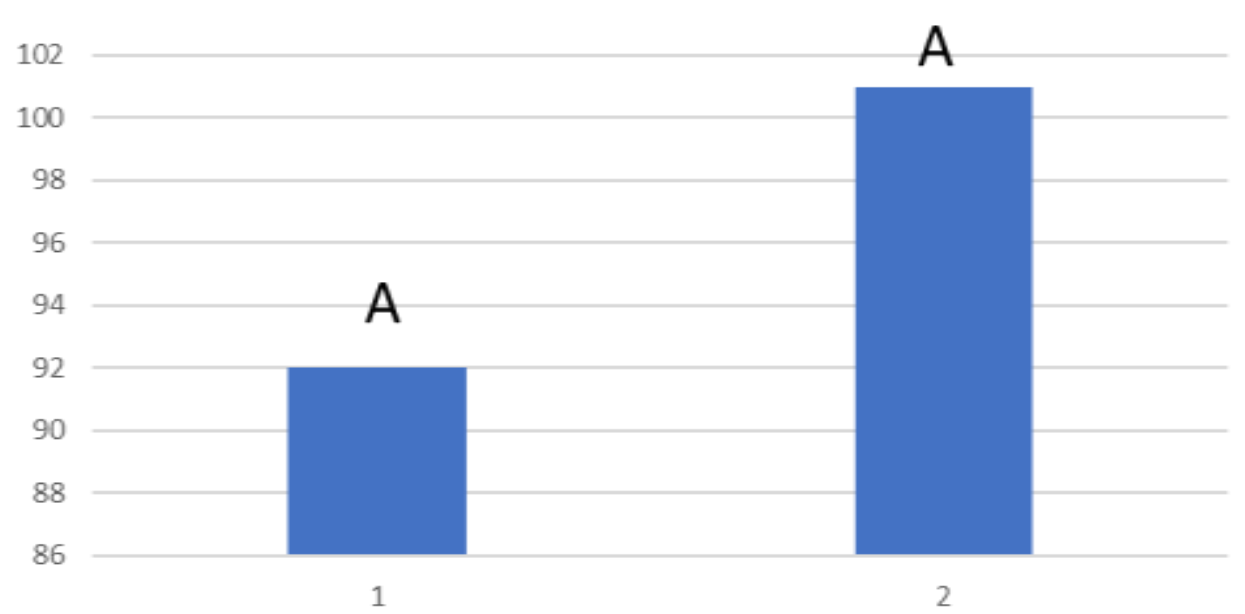

Source: Authors.

Finally, in question 5, there was a significant difference between groups 1 and 2 , in which $74.48 \%$ of group 1 prefer to 
be attended by vaccinated professionals, instead of only $56.07 \%$ of group 2 (Figure.3).

Figure 3. The answers rate of question 5. Different letters indicate statistical difference between the groups. $(1=$ group $1 ; 2=$ group 2).

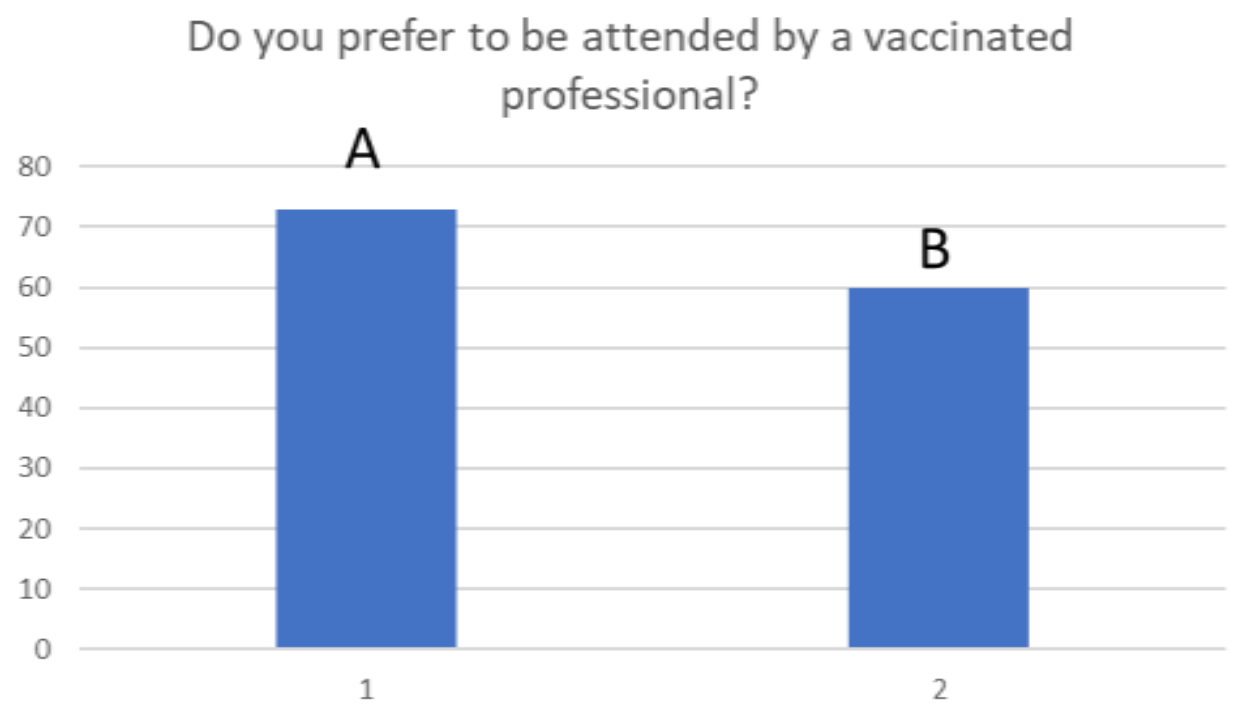

Source: Authors.

\section{Discussion}

Covid-19 pandemic affected the dental care services all over the world (Bhanushali et al., 2020; Wu, Wu, Nguyen, \& Tran, 2021; Yang, Zhou, Liu, \& Tan, 2020). Diverse studies were published in the literature trying to propose protocols to decrease the risk of contamination among patients and health workers including dentists (Jurema et al., 2020; K1lıçarslan et al., 2020; Pan et al., 2020). To the best of our knowledge, little or no questionnaires were elaborated to understand the impact of the Covid-19 pandemic over the dental patients.

There is no doubt that the covid-19 affected the dental patients' choices, alternatives and behavior (Jiang, Tang, Mei, $\& \mathrm{Li}, 2020)$. Many of patients were seeking dental care in hospitals in the first months of the pandemic where many procedures were practiced according to the clinical practice guideline (Wu et al., 2021). In the literature, it was stated through a web-based survey that the patients are less concerned with their dental health, as they are still wearing masks, patients show less demand of the dental health care (Pinzan-Vercelino et al., 2021; Ribeiro et al., 2021). In the present study, it was found that 100\% of the participants seek dental health care, however, the questionnaire was destinated for patients at dental office or dental clinic of a school. Conversely, it was found that the patients of private dental offices feel less safe while seeking the dental health care in the pandemic time, differently of the patients of the school or primary health unit. This is may be explained by the financial conditions of the patients and their awareness about the pandemic (Schwendicke, Krois, \& Gomez, 2020). It seems like the gender and geographic location has an effect on the patients fear too, only one third of the participants in another study accepted to seek dental care during the Covid-19 pandemic as related in a recent study destinated for 606 participants (Nazir et al., 2021)

On the other hand, both groups feel satisfied and safe with the professionals PPE which was indicated by the WHO and diverse national and international authorities basing on studies tried to explain the relevance and function of each equipment (Jurema et al., 2020; Pan et al., 2020), as well-established infection control is the viable proposal for current and future pandemics (Schlenz et al., 2021). This finding agree with the outcomes of another study that reported a high acceptance 
rate of compliance to the used protocols during the Covid-19 pandemic to control the virus spread in dental clinics especially during the orthodontic treatments (Umeh, Utomi, Isiekwe, \& Aladenika, 2021).

In question 4 , which was only destinated for the participants of groups 2 , it was found that $59.81 \%$ of the participants do not feel insecure with the cross contamination caused by SARS-CoV-2 in collective health care units. Again, this may be related to the patient financial conditions and their awareness about the pandemic (Schwendicke et al., 2020), and to the influence of the dentists on dental patients choices (Ahmed et al., 2020).

In question 5, it was found that only $56.07 \%$ of group 2 prefer to be attended by vaccinated professionals, while a significant difference was found with group 1 that reached $74.48 \%$. there is no doubt that the covid-19 vaccines are facing problems to be accepted by the patients all over the world, and in some cases among dental and medical students (Kelekar, Lucia, Afonso, \& Mascarenhas, 2021; Mascarenhas, Lucia, Kelekar, \& Afonso, 2021). However, it was found that dentists may help in revealing patients concerns about the Covid-19 vaccines (Kelekar et al., 2021; Marquez, Gosnell, Thikkurissy, Schwartz, \& Cully, 2021), and the first step should be the professionals themselves being vaccinated serving as example (Kaplan, Sahin, Parildar, \& Adadan Guvenc, 2021) to enhance the populations acceptance about the Covid-19 vaccines (Papagiannis et al., 2021).

\section{Conclusion}

- Not all dental patients feel safe while seeking dental treatment during the Covid-19 pandemic.

- Dental patients feel safe with the professional PPE and consider it sufficient.

- Patients feel safe to be attended by vaccinated professionals.

\section{Acknowledgments}

The authors deny any conflict of interest.

\section{References}

Abu Hasna, A., Ferrari, C. H., Bittencourt, T. S., Camargo, C. H. R., \& Carvalho, C. A. T. (2019). Acting and knowledge of emergency rescue teams in dental trauma. Brazilian dental science, 22(3), 329-334. 10.14295/bds.2019.v22i3.1717

Ahmed, M. A., Jouhar, R., Adnan, S., Ahmed, N., Ghazal, T., \& Adanir, N. (2020). Evaluation of Patient's Knowledge, Attitude, and Practice of CrossInfection Control in Dentistry during COVID-19 Pandemic. European journal of dentistry, 14(S 01), S1-S6. 10.1055/s-0040-1721295

Bhanushali, P., Katge, F., Deshpande, S., Chimata, V. K., Shetty, S., \& Pradhan, D. (2020). COVID-19: Changing Trends and Its Impact on Future of Dentistry. International journal of dentistry, 2020, 8817424. 10.1155/2020/8817424

Callaway, E. (2021). Could new COVID variants undermine vaccines? Labs scramble to find out. Nature, 589(7841), 177-178. 10.1038/d41586-021-00031-0

Hasna, A A, Pinto, A. B. A., Minhoto, G. B., Carvalho, C. A. T., \& Ferrari, C. H. (2020). Pictograph system for diagnosis making and data management in endodontics | [Sistema de pictograma para elaboração de diagnóstico e gerenciamento de dados em endodontia]. Brazilian Dental Science, 23, 1-6.

Hasna, Amjad Abu, \& Bresciani, E. (2021). Systematic review of the effect of endodontic irrigants over coronaviruses. Research, Society and Development, 10(6), e23810615457. 10.33448/rsd-v10i6.15457

Jiang, Y., Tang, T., Mei, L., \& Li, H. (2020). COVID-19 affected patients' utilization of dental care service. Oral Diseases. 10.1111/odi.13568

Jurema, A. L. B., Rocha, R. S., Mailart, M. C., De Souza, M. Y., Gonçalves, S. E. de P., Caneppele, T. M. F., \& Bresciani, E. (2020). Protocols to control contamination and strategies to optimize the clinical practice in Restorative Dentistry during the COVID-19 pandemic. Brazilian dental science, 23(2). $10.14295 /$ bds.2020.v23i2.2256

Kaplan, A. K., Sahin, M. K., Parildar, H., \& Adadan Guvenc, I. (2021). The willingness to accept the COVID-19 vaccine and affecting factors among healthcare professionals: A cross-sectional study in Turkey. International Journal of Clinical Practice, 75(7), e14226. 10.1111/ijcp.14226

Kelekar, A. K., Lucia, V. C., Afonso, N. M., \& Mascarenhas, A. K. (2021). COVID-19 vaccine acceptance and hesitancy among dental and medical students. Journal of the American Dental Association (1939), 152(8), 596-603. 10.1016/j.adaj.2021.03.006 
Kılıçarslan, M. A., Şenel, F. Ç., \& Özcan, M. (2020). Assessment of dental care during the covid-19 pandemic in Turkey and future projections. Brazilian dental science, 23(2). 10.14295/bds.2020.v23i2.2260

Kim, J.-M., Chung, Y.-S., Jo, H. J., Lee, N.-J., Kim, M. S., Woo, S. H., \& Han, M.-G. (2020). Identification of Coronavirus Isolated from a Patient in Korea with COVID-19. Osong public health and research perspectives, 11(1), 3-7. 10.24171/j.phrp.2020.11.1.02

Lima, E. J. da F., Almeida, A. M., \& Kfouri, R. de Á. (2021). Vaccines for COVID-19 - state of the art. Revista Brasileira de Saúde Materno Infantil, 21(suppl 1), 13-19. 10.1590/1806-9304202100s100002

Mandala, V. S., McKay, M. J., Shcherbakov, A. A., Dregni, A. J., Kolocouris, A., \& Hong, M. (2020). Structure and drug binding of the SARS-CoV-2 envelope protein transmembrane domain in lipid bilayers. Nature Structural \& Molecular Biology, 27(12), 1202-1208. 10.1038/s41594-020-00536-8

Marquez, R. R., Gosnell, E. S., Thikkurissy, S., Schwartz, S. B., \& Cully, J. L. (2021). Caregiver acceptance of an anticipated COVID-19 vaccination. Journal of the American Dental Association (1939). 10.1016/j.adaj.2021.03.004

Mascarenhas, A. K., Lucia, V. C., Kelekar, A., \& Afonso, N. M. (2021). Dental students' attitudes and hesitancy toward COVID-19 vaccine. Journal of dental education. 10.1002/jdd.12632

Mohamadian, M., Chiti, H., Shoghli, A., Biglari, S., Parsamanesh, N., \& Esmaeilzadeh, A. (2021). COVID-19: Virology, biology and novel laboratory diagnosis. The Journal of Gene Medicine, 23(2), e3303. 10.1002/jgm.3303

Nazir, M., Almulhim, K. S., AlDaamah, Z., Bubshait, S., Sallout, M., AlGhamdi, S., \& Alhumaid, J. (2021). Dental Fear and Patient Preference for Emergency Dental Treatment Among Adults in COVID-19 Quarantine Centers in Dammam, Saudi Arabia. Patient preference and adherence, 15, $1707-1715$. 10.2147/PPA.S319193

Nishwa, D. E., Riaz, H. A., Fatima, A., \& Wahid, B. (2020). An update on Sars-CoV-2: a review. Theoretical biology forum, 113(1-2), 47-54. $10.19272 / 202011402005$

O’Toole, Á., Scher, E., Underwood, A., Jackson, B., Hill, V., McCrone, J. T., \& Rambaut, A. (2021). Assignment of epidemiological lineages in an emerging pandemic using the pangolin tool. Virus evolution. 10.1093/ve/veab064

Pan, Y., Liu, H., Chu, C., Li, X., Liu, S., \& Lu, S. (2020). Transmission routes of SARS-CoV-2 and protective measures in dental clinics during the COVID19 pandemic. American journal of dentistry, 33(3), 129-134.

Papagiannis, D., Rachiotis, G., Malli, F., Papathanasiou, I. V., Kotsiou, O., Fradelos, E. C., \& Gourgoulianis, K. I. (2021). Acceptability of COVID-19 Vaccination among Greek Health Professionals. Vaccines, 9(3). 10.3390/vaccines9030200

Pinzan-Vercelino, C.-R.-M., Freitas, K.-M.-S., Girão, V.-M.-P., da Silva, D. O., Peloso, R.-M., \& Pinzan, A. (2021). Does the use of face masks during the COVID-19 pandemic impact on oral hygiene habits, oral conditions, reasons to seek dental care and esthetic concerns? Journal of clinical and experimental dentistry, 13(4), e369-e375. 10.4317/jced.57798

Ribeiro, L. M. C. de A. V., Ferreira, M. M., Lima, J. G. da C., Farias, D. M., Santos, A. A. dos, Medeiros, C. K. S., \& Oliveira, R. D. B. de. (2021). The impact of the COVID-19 pandemic on children's dental care in the Unique Health System of João Pessoa - PB. Research, Society and Development, 10(5), e17110515089. 10.33448/rsd-v10i5.15089

Schlenz, M. A., Schmidt, A., Wöstmann, B., May, A., Howaldt, H.-P., Albert, D., \& Schulz-Weidner, N. (2021). Perspectives from Dentists, Dental Assistants, Students, and Patients on Dental Care Adapted to the COVID-19 Pandemic: A Cross-Sectional Survey. International Journal of Environmental Research and Public Health, 18(8). 10.3390/ijerph18083940

Schwendicke, F., Krois, J., \& Gomez, J. (2020). Impact of SARS-CoV2 (Covid-19) on dental practices: Economic analysis. Journal of dentistry, 99, 103387. 10.1016/j.jdent.2020.103387

Tian, H. Y. (2020). [2019-nCoV: new challenges from coronavirus]. Zhonghua Yu Fang Yi Xue Za Zhi [Chinese Journal of Preventive Medicine], 54(3), 235238. 10.3760/cma.j.issn.0253-9624.2020.03.002

Tian, X., Li, C., Huang, A., Xia, S., Lu, S., Shi, Z., \& Ying, T. (2020). Potent binding of 2019 novel coronavirus spike protein by a SARS coronavirus-specific human monoclonal antibody. Emerging microbes \& infections, 9(1), 382-385. 10.1080/22221751.2020.1729069

To, K. K.-W., Tsang, O. T.-Y., Yip, C. C.-Y., Chan, K.-H., Wu, T.-C., Chan, J. M.-C., \& Yuen, K.-Y. (2020). Consistent detection of 2019 novel coronavirus in saliva. Clinical Infectious Diseases, 71(15), 841-843. 10.1093/cid/ciaa149

Umeh, O. D., Utomi, I. L., Isiekwe, I. G., \& Aladenika, E. T. (2021). Impact of the coronavirus disease 2019 pandemic on orthodontic patients and their attitude to orthodontic treatment. American Journal of Orthodontics and Dentofacial Orthopedics, 159(5), e399-e409. 10.1016/j.ajodo.2020.11.030

World Health Organization. (2021, August 4). Tracking SARS-CoV-2 variants. Retrieved August 7, 2021, from https://www.who.int/en/activities/trackingSARS-CoV-2-variants/

Wu, K. Y., Wu, D. T., Nguyen, T. T., \& Tran, S. D. (2021). COVID-19's impact on private practice and academic dentistry in North America. Oral Diseases, 27 Suppl 3, 684-687. 10.1111/odi.13444

Yang, Y., Zhou, Y., Liu, X., \& Tan, J. (2020). Health services provision of 48 public tertiary dental hospitals during the COVID-19 epidemic in China. Clinical oral investigations, 24(5), 1861-1864. 10.1007/s00784-020-03267-8

Zhou, P., Yang, X.-L., Wang, X.-G., Hu, B., Zhang, L., Zhang, W., \& Shi, Z.-L. (2020). A pneumonia outbreak associated with a new coronavirus of probable bat origin. Nature, 579(7798), 270-273. 10.1038/s41586-020-2012-7 